\title{
Educational Intervention Aimed at Street Food Vendors to Improve Knowledge and Practices on Food Safety and Hygiene
}

\author{
R.P.P. Karunapema \\ Ministry of Health, Sri Lanka
}

\begin{abstract}
Background: Street foods is ready- to- eat foods and beverages prepared which are sold by vendors in streets and other public places for immediate consumption or consumption at a later time without further processing or preparation. Street vended foods forms a distinctive part of food industry because they are mostly affordable, easily accessible. Food handlers play an important role in food safety and in transmission of food poisoning, because they can introduce pathogens into foods during production, processing, distribution and serving. Therefore, the understanding of food safety procedures and the potential factors that causes food borne diseases is very essential for all food handlers.

Objective: The study was conducted with the objective of assessing the level of knowledge and practices on food safety and hygiene in street food vendors and improve the knowledge and practices through an educational intervention targeting the street food vendors.

Methods: A descriptive cross-sectional study was conducted to assess the knowledge and practices of the street food vendors. An educational intervention was carried out using the mode of one-to-one knowledge sharing discussion facilitated by pictorial materials. The intervention was conducted in all street food vendors in a selected medical Officer of Health area in the Colombo district. Similar $\mathrm{MOH}$ area in the Colombo district was used as the control area. Interviewer administered questionnaire was used to assess the level of knowledge and a checklist was used to assess the practices.

Results: The knowledge and practices level were not satisfactory in the baseline study. The knowledge improved in a statistically significant proportion $(\mathrm{P}<0.05)$ following the intervention in the intervention group. However, the level of improvement of practices was not statistically significant at the post interventional assessment $(\mathrm{P}>0.05)$.

Conclusions: The intervention was successful in improving the knowledge of the street food vendors significantly. However, the practice level did not show a statistically significant improvement.
\end{abstract}

KEY WORDS: Educational intervention, Food safety and hygiene, Street food vendors

\section{INTRODUCTION}

Street food safety remains a major problem in most developing countries. ${ }^{1}$ Asian food culture has a long history of street food. Most cities provide street food for locals and tourists, and street food has become part of the local culture. Therefore, street food safety has become a matter of safety concern for public health officials, and has been shown to be served in poor food handling and unsanitary conditions. ${ }^{2,3,4}$ Most street food vendors are relatively uneducated and often uninformed, and have little regulatory or supervisory oversight of this informal sector. In some developing countries, street food has been associated with outbreaks of foodborne diseases which are underreported ${ }^{6,7}$ High levels of coliform bacteria have been found in street food in many countries, and street food has been identified as a common medium for transmission of antimicrobial-resistant pathogens.

Street foods have now become a major source of food for most homes and individuals especially in developing countries due to changing socio economic patternn. ${ }^{8}$ It is consumed by about 2.5 billion people worldwide on daily basis. This is because most people spend less time at their home due to busy work schedules and therefore depend on street foods. Street foods are relatively inexpensive, easily accessible, and offer a variety of meals to consumers. ${ }^{9,10}$ The street food industry is therefore growing at a very fast rate worldwide. It has become a source of employment and income for individuals and homes. Increasing unemployment rates and poverty are also major factors that influence people to venture into street food business because it requires minimal capital and skills to set up. 


\section{International Journal of Current Science Research and Review}

ISSN: 2581-8341

Volume 04 Issue 11 November 2021

DOI: 10.47191/ijcsrr/V4-i11-09, Impact Factor: 5.825

Street food vending is a thriving business, especially in the developing countries, and it is one of the most common business practices globally, as it generates income in many of the low-income households especially in urban settings.$^{11,12}$ Street food vendors are estimated to feed more than $50 \%$ of the urban population in developing countries. However, street vended foods may be a source of many foodborne pathogens and illnesses if not regulated or properly handled. For example, there is no uniformity on the regulations for informal trading, which includes street food vending. Knowledge of safe food handling and hygiene is vital for street food vending as it may reduce foodborne infections. ${ }^{13,14}$ However, knowledge alone may not always lead to desired food hygiene practices, as other factors such as water resources, socio-demographics and cultural practices play a role as well.

According to the WHO, globally, one out of every ten persons contract food-borne illnesses. Over ninety-one million people acquire food-borne illnesses every year with resultant deaths of about one hundred and thirty seven thousand..$^{15}$ Street foods have been linked with numerous food-borne illnesses and food poisoning outbreaks specially in developing world. This has led to a growing public health concern on food safety. ${ }^{16}$ The activities of street food vendors are therefore regulated in many countries.

The World Health Organization has recommended five key strategies to address food safety. ${ }^{17}$ These include separating raw and cooked food, using safe water and raw materials, cooking thoroughly, keeping food at safe temperatures, and keeping clean all utensils. These strategies have been adopted by several training programs for street food vendors especially in developing countries. Despite all these efforts, there are, however, major gaps in the operations of food safety regulatory institutions and the laws governing food safety, knowledge of food vendors on safety food practices, and the food-handling practices of street food vendors. This has led to substandard food safety practices by food vendors and resulted in food borne diseases in the population.

\section{METHODS}

The study was conducted as an interventional study. Two Medical Officers of Health areas where street food vendors commonly operate were selected purposefully. Of the selected two areas the intervention and the control group were assigned randomly. The areas selected were not adjacent to each other to prevent contamination. $\mathrm{MOH}$ areas in the Colombo district was selected due to the fact that unlike in the other areas there are a large migratory population and considerable proportion patronage the street food vendors. All street food vendors in the selected area were included in the study. They were assigned a unique identification number and their details were recorded for the purpose of tracking the vendors for the post interventional assessment.

The pre interventional assessment was carried out using an interviewer administered knowledge questionnaire and a checklist to assess the practices. The knowledge questionnaire contained questions in the following areas;

Food safety

Personal hygiene

Clean utensils and surfaces

Storage of food items

Serving of food to customers

Maintaining proper temperature

Disposal of waste

Food borne diseases

The checklist used for the assessment of the practices included the following areas;

Cleanliness of the utensils

Food preparation practices

Food serving practices

Cleaning practices

Personal hygiene of the vender

Cleanliness of the environment, safety practices,

Educational intervention was mainly through discussion. This approach was important since a uniform educational method cannot be implemented to all street food vendors since the vendors are of different educational level and most with no formal education. 


\section{International Journal of Current Science Research and Review}

ISSN: 2581-8341

Volume 04 Issue 11 November 2021

DOI: 10.47191/ijcsrr/V4-i11-09, Impact Factor: 5.825

IJCSRR @ 2021

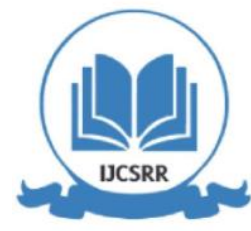

www.ijesrr.org

The discussion was facilitated by pictorial depictions. The vendors were encouraged to ask questions and clarifications were made. They were made aware of the legal requirements on food safety and hygiene practices under the Food Act.

\section{RESULTS}

The knowledge level in all the areas tested showed that there was no statistically significant difference between the intervention and the control group. However, the post intervention results showed that in all areas, the intervention group has shown a statistically significant improvement compared to the control group.

Table 1: Distribution of level of knowledge between intervention and control group

\begin{tabular}{|l|l|l|}
\hline Area & $\begin{array}{l}\text { Pre intervention } \\
\text { (P value) }\end{array}$ & $\begin{array}{l}\text { Post intervention } \\
\text { (P value) }\end{array}$ \\
\hline Food safety & $\mathrm{P}>0.05$ & $\mathrm{P}<0.05$ \\
\hline Personal hygiene & $\mathrm{P}>0.05$ & $\mathrm{P}<0.05$ \\
\hline Clean utensils and surfaces & $\mathrm{P}>0.05$ & $\mathrm{P}<0.05$ \\
\hline Storage of food items & $\mathrm{P}>0.05$ & $\mathrm{P}<0.05$ \\
\hline Serving of food to customers & $\mathrm{P}>0.05$ & $\mathrm{P}<0.05$ \\
\hline Maintaining proper temperature & $\mathrm{P}>0.05$ & $\mathrm{P}<0.05$ \\
\hline Disposal of waste & $\mathrm{P}>0.05$ & $\mathrm{P}<0.05$ \\
\hline Food borne diseases & $\mathrm{P}>0.05$ & $\mathrm{P}<0.05$ \\
\hline
\end{tabular}

The mean knowledge score showed that the intervention group had a statistically significant difference compared to the intervention group.

Table 2: Distribution by knowledge in the post interventional assessment

\begin{tabular}{llll}
\hline Knowledge & $\begin{array}{l}\text { Intervention } \\
\text { Group Score }\end{array}$ & $\begin{array}{l}\text { Control } \\
\text { Group Score }\end{array}$ & P Value \\
\hline Mean knowledge score & 62.3 & 43.6 & $<0.05$ \\
\hline
\end{tabular}

The practices were assessed using a checklist. The mean practices score of the intervention and the control group did not show a major difference. The difference was not statistically significant.

Table 3: Distribution by practice in the post interventional assessment

\begin{tabular}{llll}
\hline Practice & $\begin{array}{l}\text { Intervention } \\
\text { Group Score }\end{array}$ & $\begin{array}{l}\text { Control } \\
\text { Group Score }\end{array}$ & P Value \\
\hline $\begin{array}{l}\text { Mean } \\
\text { practice score }\end{array}$ & 47.3 & 41.5 & $>0.05$ \\
\hline
\end{tabular}

The results indicate that the intervention has resulted in statistically significant improvement in the level of knowledge in the intervention group at the post interventional assessment. However, the intervention was not effective to create a statistically significant difference at the post interventional assessment. 


\title{
International Journal of Current Science Research and Review
}

ISSN: 2581-8341

\author{
Volume 04 Issue 11 November 2021 \\ DOI: 10.47191/ijcsrr/V4-i11-09, Impact Factor: 5.825 \\ IJCSRR @ 2021
}

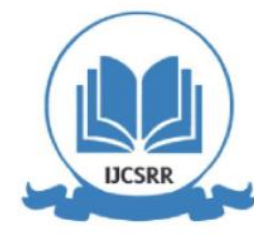

www.ijcsrr.org

\section{DISCUSSION}

The knowledge of the food handlers was not satisfactory in the intervention and the control group at the baseline survey. However, the educational intervention was successful to create and statistically significant improvement at the post intervention assessment. The knowledge was tested in the basic areas on food safety and hygiene where any food handler is expected to be aware of. These areas included; Food safety, Personal hygiene, Clean utensils and surfaces, Storage of food items, Serving of food to customers, Maintaining proper temperature, Disposal of waste and Food borne diseases. Having a low score in these essential areas indicate that the street food vendors have either not been assessed by authorised offices or have been a neglected category.

The practices too showed a poor score indicating the poor level of practices at te baseline survey. However, the scores for the practices did not increase in a statistically significant proportion during the post interventional assessment. This indicate although the knowledge improved, the practices were not improved to a significant proportion following the intervention.

The level of practices depends on many factors. Even though the street food vendor has a satisfactory knowledge, other factors such as economic factors, availability of water sources, limited space and mobility may have contributed to the poor practices.

The authorised officers under the Food Act can play a major role in the improvement of food safety and hygiene in the street food vendors. The knowledge can be imparted by the Public Health Inspectors who are authorised officers during the inspections. The inspections should be carried out on regular basis. When there are regular inspections, the vendors will be compelled to improve the practices to a satisfactory level to avoid prosecutions. Therefore, educating the street food vendors should be coupled with regular inspection by Public Health Inspectors.

\section{CONCLUSION}

The educational intervention was effective in causing a statistically significant improvement in the knowledge level of the street food vendors. However, the intervention was not effective in creating a significant improvement the practices. The improvement of the practices may be successfully achieved if the imparting of knowledge is coupled with regular inspection by the Public Health Inspectors.

\section{REFERENCE}

1. Monney, D. Agyei, B. S. Ewoenam, C. Priscilla, and S. Nyaw, "Food hygiene and safety practices among street food vendors: an assessment of compliance, institutional and legislative framework in Ghana," Food and Public Health, vol. 4, no. 6, pp. 306-315, 2014.

2. C. Muyanja, L. Nayiga, N. Brenda, and G. Nasinyama, "Practices, knowledge and risk factors of street food vendors in Uganda," Food Control, vol. 22, no. 10, pp. 1551-1558, 2011.

3. E. Donkor, B. Kayang, J. Quaye, and M. Akyeh, "Application of the WHO keys of safer food to improve food handling practices of food vendors in a poor resource community in Ghana," International Journal of Environmental Research and Public Health, vol. 6, no. 11, pp. 2833-2842, 2009.

4. G. Tessema, K. A. Gelaye, and D. H. Chercos, "Factors affecting food handling Practices among food handlers of Dangila town food and drink establishments, north west Ethiopia," BMC Public Health, vol. 14, no. 1, p. $571,2014$.

5. O. Chukuezi, "Food safety and hygienic practices of street food vendors in Owerri, Nigeria," Studies in Sociology of Science, vol. 1, no. 1, p. 50, 2010.

6. Lamuka PO. Public health measures: challenges of developing countries in management of food safety. Encycl of Food Saf. 2014;4:20-6.

7. Karasavvidou E. Hygienic and sanitary practices of vendors of street foodsin Nairobi. Kenya Afr J Food Agric Nutr Dev. 2005;1:649-50.

8. Anandhi N, Janani, Krishnaveni N. microbiological quality of selected street-vended foods in Coimbatore, India. Afr J Microbiol Res. 2015;9(11):757-62.

9. Lues JFR, Mpeli RR, Venter P, Theron MM. Assessing food safety and associated food handling practices in street food vending. Int J Environ Health Res. 2006;6:319-28 


\section{International Journal of Current Science Research and Review}

ISSN: 2581-8341

Volume 04 Issue 11 November 2021

DOI: 10.47191/ijesrr/V4-i11-09, Impact Factor: 5.825

10. S. Samapundo, R. Climat, R. Xhaferi, and F. Devlieghere, "Food safety knowledge, attitudes and practices of street food vendors and consumers in Port-au-Prince, Haiti," Food Control, vol. 50, pp. 457-466, 2015.

11. O. K. Muinde and E. Kuria, "Hygienic and sanitary practices of vendors of street food in nairobi, Kenya," Africa Journal of Food, Agriculture, Nutrition and Development, vol. 5, no. 1, 2005

12. T. N. C. Thanh, "Food safety behavior, attitudes and practices of street food vendors and consumers in Vietnam," 2015, http://lib.ugent.be/fulltxt/RUG01/002/217/245/RUG01-002217245_2015_0001_AC.pdf

13. S. Apanga, J. Addah, and D. R. Sey, "Food safety knowledge and practice of street food vendors in rural northern Ghana," Food and Public Health, vol. 4, no. 3, pp. 99-103, 2014

14. Food and Agriculture Organization of United Nations, "Street food in urban Ghana: a desk top review and analysis and recommendations from existing literature," 2016, http://www.fao.org/3/a-i5804e.pdf

15. BB, Zheng FT. Current situation analysis of local food safety and evaluation index design for local government supervision. Food Ind. 2017;2:279-82.

16. World Health Organization, "WHO's first ever global estimates of foodborne diseases," 2015 http://www.who.int/mediacentre/news/releases/2015/foodborne-disease-estimates/en/

17. World Health Organization, Essential Safety Requirements for Street-Vended Foods (No. WHO/FNU/FOS/96.7 Rev1), World Health Organization, Geneva, Switerzland, 1996.

Cite this Article: R.P.P. Karunapema (2021). Educational Intervention Aimed at Street Food Vendors to Improve Knowledge and Practices on Food Safety and Hygiene. International Journal of Current Science Research and Review, 4(11), $1544-1548$ 